\title{
Recontextualization Audio Visual In Film Warkop DKI 70s Chips Into Warkop DKI Reborn (2016)
}

\author{
Kurniawan Akhmad Muzaki ${ }^{1}$, Anggar Erdhina Adi ${ }^{2}$ \\ ${ }^{1}$ Visual Communication Design Study Program, Telkom University, Bandung, Indonesia \\ ${ }^{2}$ Visual Communication Design Study Program, Telkom University, Bandung, Indonesia \\ kiki.zaki@yahoo.com (Kurniawan Akhmad Muzaki),anggarwarok@telkomuniversity.ac.id (Anggar Erdhina Adi)
}

\begin{abstract}
This Tresearch discusses audio video recontextualization of 1970s Warkop DKI movies into 2016's Warkop DKI Reborn. Both movies have contextual similarity in which the latter repeat the context of the former. The purpose of the research is to find out the characteristics and contextualization in terms of audio and visuall, by using qualitative research method with descriptive analysis that draws comparison of audio and visual data of both movies. The theories employed in the research include: recontextualization, theory of comedy in movies, and theory of audio. As the result, there is an effort to recontextualize 1970s Warkop DKI movies into Warkop DKI Reborn to adjust with the 2016 era. Therefore, the result of the research shows the attempts of maintaining the audio-visual characteristics of both movies, more specifically by representation of 1970s audio video tenets to the reproduction of the same movie in 2016.
\end{abstract}

Keywords recontextulization, audio-visual, comparison

\section{INTRODUCTION}

Movie is one of the best attractions in nowadays culture. The emergence of cinema in society seems to facilitate enjoyment of movies. Moreover, specifically Indonesian production makes movies in relation with the happening phenomenon around the country. By concerning everyday matters of society, movie becomes attached with the identity of Indonesian people.

On the other hand, the elements of comedy or humor help with the delivery of the movie's message to its spectators. Comedy becomes a point of attraction contributes to the success of a movie with its advantage in catching viewers. Comedy is interesting that it provides joy, happiness and satisfaction.

Indonesian comedy movie industry achieved its success in 1970s era with the appearance of popular comedians such as Suratmi B-29 in the movie Ali Baba, Tarsan Pensiunan and Diana. Another is a typically Betawian-style Benyamin S. Who appeared in various movies like Benteng Betawi, Ratu Amplop, Raja Copet, etc. Additionally, Indonesian entertainment in that era is strongly characterized with country music, 70s pop and dangdut. Such phenomenon was all represented in the available comedy movies that reached significant attraction.

In 1970s period, in particular, appeared three succesful comedian figures that formed a group called "Warkop DKI." They were known as Dono (Wahjoe
Sardono), Kasino (Kasino Hardiwibowo) and Inro (Indrodjojo Kusumonegoro). After earlier nine years career in radio broadcasting, they had opportunity to appear in film industry in 1979 with their first and most successful box office movie in its day, "Mana Tahan." In their early movie they appeared with the style of college student of that era. The movie construed a story of daily ordinary life of Indonesian society. Such appearance of comedian group is considered as a new wave of Indonesian comedy entertainment compared to the common individual comedian appearance in that era.

Their unique identity was their typical dialogue tone, sound effect as well as visual effect in their movies that contributed to the humorous value of their work. Audio and visual touch of their movies was strongly related to Indonesian cultural characteristic of that era. For example, they included popular music in their movies to bridge their connection to the community. Such music was presented by collegian style presented with critics against government in that period. Additionally, they combined them with various country music that finally formed their signature Warkop DKI theme song.

After decades, particularly in 2016, adapted movie of 1970s Warkop DKI movie was released entitled Warkop DKI Reborn. It was a cure of nostalgic spectators of 1970 s version of the movie, that helps reveal their past memories of enjoyment. 
"Warkop DKI Reborn: Jangkrik Bos Part 1" mostly adapts the story line of 1982 Warkop DKI movie CHIPS. Moreover, though musical and visual background in the new movie is made with modern and fresher touch, it does not throw away musical base of the older movie. The visual touch of the new movie seems to change, yet it maintains visual impression of 1970s era which is natural and original. Such adaptation in this case is called recontextualization, in which adjustment of context takes place.

"...resituating of known facts and actions in

a new intellectual context...redescription from a new perspective." (Reed in Yohanes

2011: 124)

Recontextualization in the movie, in which radical shift in terms of new context and new perspective makes it different from the older version, is adjusted in accordance with its target viewers. Different case of targeted viewers between both versions is the basis of recontextualization.

Another recontextualized aspect of the movie is its audio. Audio is understood in several criteria: type of sound, dialogue, variation (dialogue technique), music, sound effect, etc. Audio is crucial because it constitutes the first element of complete audiovisualized picture. In fact, audio in comedy movie is inseparable from the storyline of the movie. Comedy movies in 1970s, particularly Warkop DKI had strong characteristics of fast rhythmic piano sound that emphasize their humor point.

Furthermore, the new movie also recontextualized the theme song of the older version, which is titled Warung Kopi. While the older version of the song is only instrumented with guitar, the new version makes additions of beats that is acceptable in current perspective. Moreover, the lyric is also contextualized by making it similar enough and involving Indro in the singing of the song. In other case, the dialogue is recontextualized by adjusting it in terms of time and space in order to adjust the tone of dialogue with the new expected perspective. Such recontextualization of relevant aspects of the movie is necessary to respond the difference of targeted viewers between both eras of the movie.

Departing from the explanation above, it is necessary to conduct a research of audio-visual recontextualization of 1970 s comedy movies, in hope that in the future Indonesian film industry can perform the best way to manage adaptation work, especially in their audio and visual adjustment. With that reason, the study of audio-visual recontextualization of 1970s Warkop Movie CHIPS into Warkop DKI Reborn 2016 is conducted.

\section{RESEARCH METHODOLOGY}

This research applies qualitative analysis by comparing two movies in the perspective of recontextualization. A qualitative research is in search of meaning, definition, concept, characteristics, symptoms, symbols or description of particular phenomenon, using various way and explained in a narrative way (Yusuf, 2014: 328).

In comparative method, distinction is made between descriptive comparison and correlational one (Kutha Ratna in Silalhi, 2009: 35-36). The former method makes comparison by description, while the latter make comparison by finding reciprocity and cause-effect relationship. Both methods may derive from available variables with different samples. In the case of this research, the variables are audio and visual aspect of the movie.

This research is conducted in this way:

\subsection{Data Collection}

The collection of the data in this research includes three types of data: documentary data, audio data and visual data.

$\square$ Documents

In this research, the documents used constitute two versions of Warkop DKI: Warkop DKI CHIPS (1982) and Warkop DKI Reborn (2016).

\section{$\checkmark$ Audio Data}

In this research, the researcher will deeply study the audio of both Warkop DKI CHIPS and Warkop DKI Reborn.

$\square$ Visual Data

Visual data is collected by framing scene by scene available within both movies. Scenes are selected from the entire movies based on their contextual similarity. After selecting relevant scene, similarity of both movies in terms of visuality can be pointed out.

\subsection{Analysis Data}

The analysis of the research is conducted with data reduction, data display and the drawing of conclusion.

\section{$\square$ Data Reduction}

The researcher conducted selection process, focusing data, simplification and separation from "raw" data obtained. In this case, research is conducted by selection of audio and video section that fulfills recontextualization criteria.

\section{$\square$ Data Display}

In this case, the researcher organize the collected information to enable further action, by means of listening, seeing and paying attention to the context that appears within each reduced audio and visual material. This is executed by cutting and capturing selected scene frames, and then studying them for couple of times to result an analysis of contextual similarity of both objects.

$\square$ Drawing Conclusion

The final stage of data analysis is to draw conclusion in which the researcher make conclusion based on the finding of the research. This conclusion will be examined in terms of accountability and truthfulness in the side of researcher regarding the contextual similarity. 


\section{THEORETICAL FRAMEWORK}

\subsection{Recontextualization \\ 3.1.1. Recontextualiation in Movie}

According to Prof. Deddy Mulyana, context has four aspects: physical, psychological, social and temporal. That is, a context communicated by a communicator or soure of message to the communicant or hearer within the scope of its aspects in accordance with communicator's purpose (Mulyana,

2012:77). In case of movie, context constitutes various elements, such as audio and visual that conceals one or some of the aspects that supports producer's purpose.

Context can also be derived from the available situation and be changed to comply with purpose by identifying its aspects. To represent that context in

another occasion is called recontextualization.

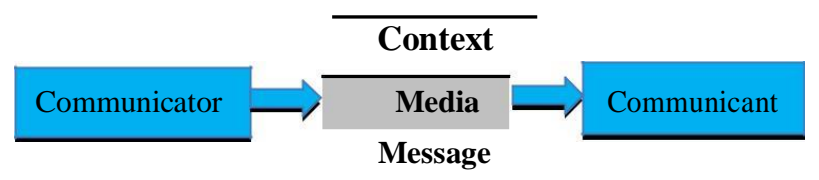

Figure 2.1.1 Context of Commuication

(Source: Buku Ilmu Komunikasi Mulyana 2012: 67)

\subsubsection{Isaac Airil's Recontextualization}

Recontextualization according to Isaac Airil (in Interpretation and Social Knowledge) is explained as follows

$$
\begin{aligned}
& \text { "to argue that what realists } \\
& \text { call }
\end{aligned}
$$

explanation is in fact redescription, which is to say, the resituating of known facts and actions in a new intellectual context. And what normativists call critique is, likewise, redescription from a new perspective, according to which previously acceptable actions become intolerable, old ways of being and acting are revealed as domineering, and visions of what can and should be acquire new life. Inquiry generally-perhaps even natural scientifi cinquiry-can be understood as recontextualization" (Ariail, 2011:124).

Recontextualization is understood as the possibility to represent a context that has appeared before, in anytime depending on the perspective that seeks to represent that context.

Warkop DKI Reborn brings about quite good reproduction in terms of acting, actors, pictureshooting, story line, audio, and so on. In this research, the researcher will raise the issue of recontextualization of audio and visual characteristics of Warkop DKI Reborn, from which new context can be derived based on the facts entailed in the older version of the movie, in the perspective of the viewers.

\subsection{Comedy in Movie}

Indonesian Humor Institution (LHI) states that humor relies on verbal, physical, and visual exploration (Suwardi 2006: 51). In effect, the dramatic structure of comedy movie is unlike any other, in a way that it provides both laugh and introspection. Helitzer points out eight factors that lead to viewer's laugh: surprise, superiority, biological relaxation,

incongruity, ambivalence, release configuration, and psychoanalysis (Suwardi, 2006: 58). Additionally, with no doubt comedy movie is inseparable from its unique audio characteristics. And it is not inseparable from its visual characteristics either since comedy relies on physical appearance visualized in the movie.

\subsection{Audio in Movie}

Sound or audio in a movie is synchronized with the picture elements. Audio includes dialogue, music, and sound effect. Mute movie was common before the existing of audible movie. However most of them were not completely mute. Sometimes they include the sound of organ, piano, gramophone, musician, sound effect, or orchestra (Pratista, 2008: 149).

\section{Dialogue}

Dialogue is verbal communication used by all character in or out the narration. Furthermore, movie dialogue may play an important role in constructing the unique identity of the movie.

\section{a. Speaking Language}

Speaking language refers to the kind of verbal communication that is used within a movie. Speaking language can be identified with the regional or periodic aspect of the movie. (Pratista, 2008: 150).

b. Accent

Accent is an important contributor to the success of a movie.

\section{Music}

Music is one important element to strengthen the mood, nuance, and environment of the movie. Music can be the soul of a movie (Pratista, 2008: 154). Music in a movie may be illustration or song (soundtrack).

a. Illustrative Music

It is the background music that accompanies actions along the storyline (Pratista, 2008: 154).

b. Song (soundtrack)

Beside illustrative music, song can form character and mood of a movie (Pratista, 2008: 156). 
Sound Effect

Sound effect of a movie is often termed as noise. All additional sound other than dialogue and song is sound effect (Pratista, 2008: 157). Sound effect manipulates an action or object.

Main Elements of Sound

a. Loudness

Loudness or volume represents the strength or weakness of sound (Pratista, 2008: 157).

b. Pitch

Pitch is determined by the frequency of the sound. The higher the frequency is, the higher the pitch will be and vice versa. Sound frequency includes low (bass), midrange (middle) and high (treble) with Hertz unit $(\mathrm{Hz})$.

\section{ANALYSIS}

While analyzing data, the researcher also displays the data to show the entailed context of both Warkop DKI: CHIPS and Warkop DKI Reborn.

4.1. Analysis of Audio and Visual Characteristics

This analysis is conducted to find out the audio-visual characteristics of both Warkop DKI CHIPS (1982) and Warkop DKI Reborn (2016).

a. Audio Characteristics Analysis

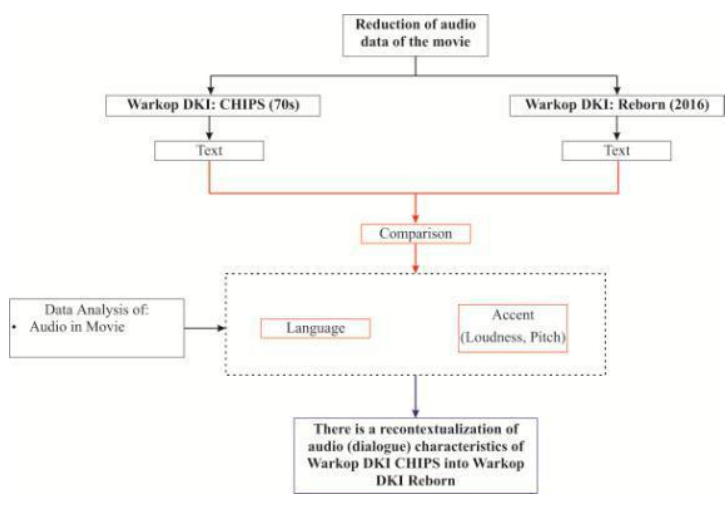

Figure 4.1.1 Analysis Scheme of Audio (Dialogue) Source: Author (2017)
Table 4.1.1 Audio Characteristics Analysis

\begin{tabular}{|c|c|c|}
\hline $\begin{array}{c}\text { Warkop DKI } \\
\text { CHIPS (1982) }\end{array}$ & Analysis & $\begin{array}{c}\text { Warkop DKI } \\
\text { Reborn (2016) }\end{array}$ \\
\hline $\begin{array}{l}\text { "Jangkrik } \\
\text { bosss..." }\end{array}$ & 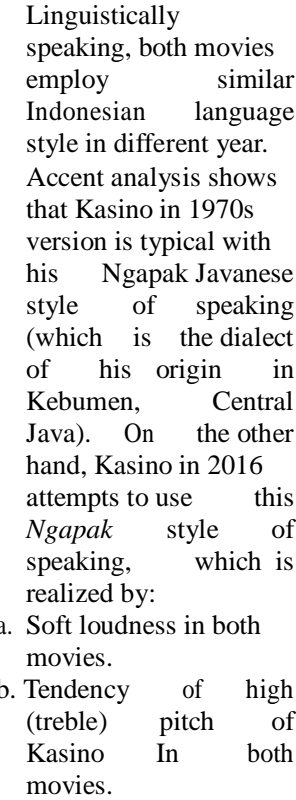 & $\begin{array}{l}\text { "Jangkrik } \\
\text { bosss..." }\end{array}$ \\
\hline
\end{tabular}

b. Visual Characteristics Analysis

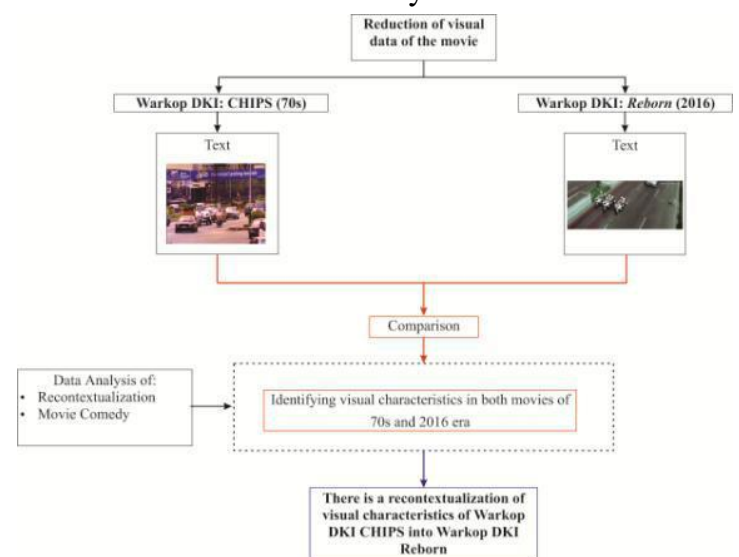

Figure 4.1.2 Analysis Scheme of Visual Characteristics Source: Author (2017)

Tabel 4.1.2 Analisis Karakteristik Visual

\begin{tabular}{|c|c|}
\hline \multicolumn{2}{|c|}{ Frame } \\
\hline $\begin{array}{c}\text { Warkop DKI: CHIPS } \\
\text { Era 70-an }\end{array}$ & $\begin{array}{c}\text { Warkop DKI Reborn : } \\
\text { Jangkrik Bos } \\
\text { Era } 2016 \\
\end{array}$ \\
\hline 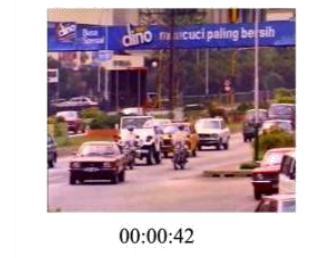 & $00: 16: 13$ \\
\hline \multicolumn{2}{|c|}{ Analysis } \\
\hline $\begin{array}{l}\text { The frames of both versi } \\
\text { similar characteristics. } 201 \\
\text { repeat the scene similar to t } \\
\text { representation process. Eve } \\
\text { the new version is made sin } \\
\text { In other words, the fram } \\
\text { picture have similar chara } \\
\text { comedy, this character is } \\
\text { introduce a movie. }\end{array}$ & $\begin{array}{l}\text { the movies seem to have } \\
\text { ion of the movie attempts to } \\
\text { 1970s version. This shows a } \\
\text { circumstance of the scene of } \\
\text { o the original. } \\
\text { both movies shown in the } \\
\text { tics in yet different era. In } \\
\text { of configurational one to }\end{array}$ \\
\hline
\end{tabular}


In audio analysis, the researcher focuses on three elements: dialogue, music and sound effect. In visual analysis, the researcher selects the parallel frame of both movies. Audio analysis shows that character Dono have similar speaking style in both movies, Kasino in 2016 emphasizes more Ngapak style of speaking, while Indro in 2016 emphasizes Batakese accent. In other words, the original movie has built a strong basis that leads the establishment of the characteristics of the new version. However, the use of dialogue language of both movies seems to differ in a way that the original is more natural, while the new version attempts to imitate the naturalness of the original. Both movies share similar musical character in which they play a lot of military-themed sound track. New version of the movie tries to do so by adding similar contextual characteristics. Both movies shares sound effect that works around accident of plunging, handy talkie effect and so on.

In visual consideration, however, there is a kind of modification of the original in the new version. For example, when framing intimate scene between the boss and his mistress, the original setting is in the garden, while the setting of the new version is the office. This shows a redelivery of characteristics of the original into the new version.

\subsection{Analysis of Audio \\ Visual}

\section{Recontextualization}

Recontextualization analysis is conducted to find out the audio-visual recontextualization that occurs in both Warkop DKI CHIPS 1982 and Warkop DKI Reborn (2016).

a. Audio Recontextualization Analysis

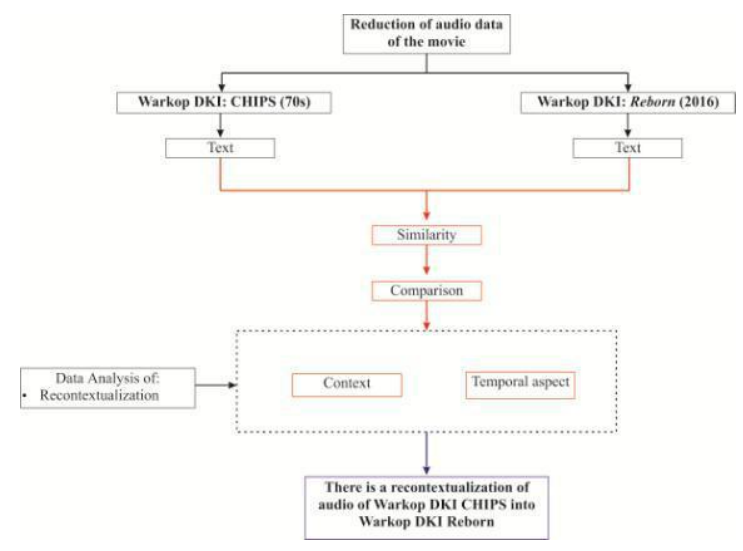

Figure 4.2.1 Analysis Scheme of Audio Recontextualization (Dialogue) Source: Author (2017)
Table 4.2.1 Audio Recontextualization Analysis (Dialogue)

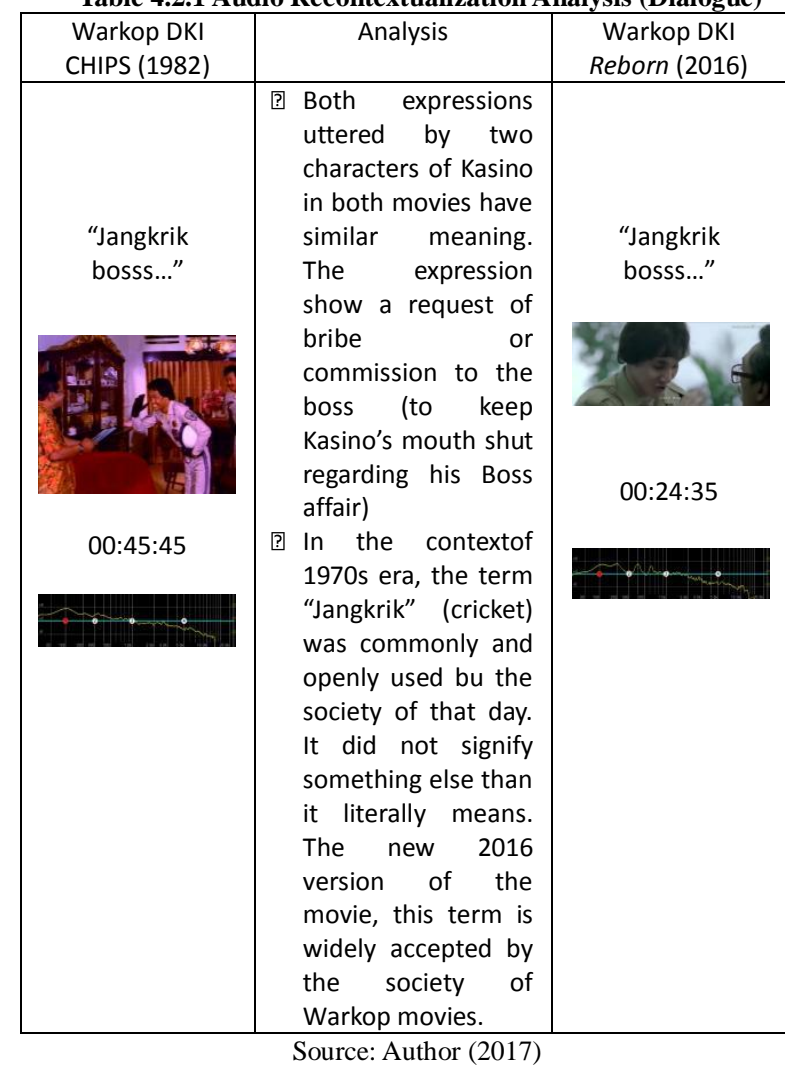

b. Visual Recontextualization Analysis

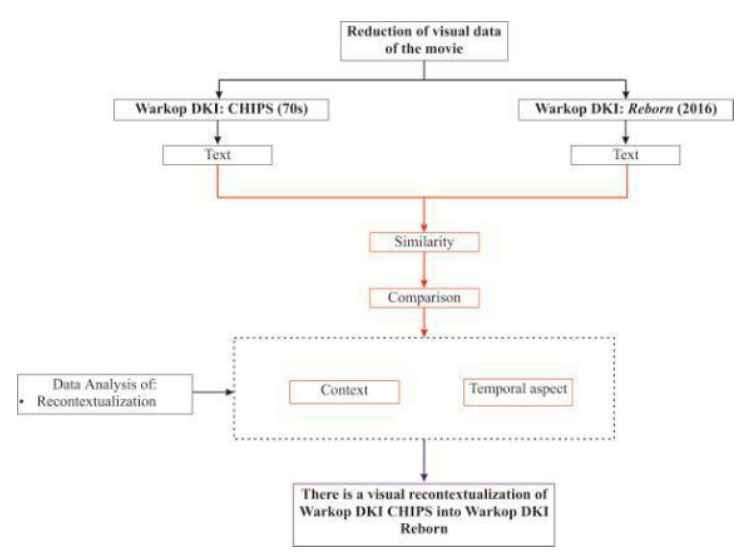

Figure 4.2.2 Analysis Scheme of Visual Recontextualization Source: Author (2017) 
Table 4.2.2 Visual Recontextualization Analysis

\begin{tabular}{|c|c|}
\hline \multicolumn{2}{|c|}{ Frame } \\
\hline $\begin{array}{c}\text { Warkop DKI: CHIPS } \\
\text { Era 70-an }\end{array}$ & $\begin{array}{c}\text { Warkop DKI Reborn : } \\
\text { Jangkrik Bos } \\
\text { Era } 2016\end{array}$ \\
\hline 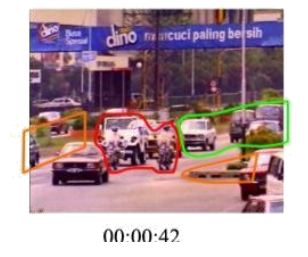 & $n 0: 16: 13$ \\
\hline \multicolumn{2}{|c|}{ Notes } \\
\hline \multicolumn{2}{|c|}{$\begin{array}{l}\text { Red } \\
\text { Shows officer patrol ride. } \\
\text { Green } \\
\text { Shows traffic vehicles following patrol convoy. } \\
\text { Orange } \\
\text { Shows road lines between two roads of opposing direction. }\end{array}$} \\
\hline \multicolumn{2}{|c|}{ Analysis } \\
\hline $\begin{array}{l}\text { Both frames are perceiv } \\
\text { characteristics. First, the } 2 \\
\text { to show introduction to th } \\
\text { that is similar to the } 1970 \\
\text { looks too far that it seems } \\
\text { was. Modern } 2016 \text { society } \\
\text { of patrolling vehicles. Sec } \\
\text { attempts excludes the diffe } \\
\text { The original version shows } \\
2016 \text { version. It is seen } \\
\text { following the patrolling ri } \\
\text { widely preferred since they } \\
\text { On the other hand, } 2016 \\
\text { colorful high-capacity cars. }\end{array}$ & $\begin{array}{l}\text { show parallel contextual } \\
\text { sion of the movie attempts } \\
\text { lling officers in the street } \\
\text { lal, however such imitation } \\
\text { backward than } 1970 \text { s really } \\
\text { ed enough by the existence } \\
\text { he successfulness of these } \\
\text { of the picturing of crowd. } \\
\text { crowded road than the new } \\
\text { frame that vehicles are } \\
1970 \text { s context, cars were } \\
\text { ded high degree of society. } \\
\text { shows the domination of }\end{array}$ \\
\hline
\end{tabular}

In terms of audio, recontextualization of Warkop DKI CHIPS 1982 into Warkop DKI Reborn 2016 includes three parts: dialogue, music, and sound effect. And the result is the similarity of audio characteristics between Warkop DKI CHIP and Warkop DKI Reborn. For example, both movies have similar scene where Kasino approach the boss to have dialogue in which the Boss give him mouth-shutting money to keep the Boss affair in secret. In 1970s era, common expression of blackmailing would be "money to buy cigarette," since 1970s society associates bribe or tips with cigarette. In comparison, 2016 society nowadays adapt the expression of blackmailing by saying "money to buy phone credit." Furthermore, the use of music is also significantly different. In 1970s Warkop movie, music is plainly entailed with very limited modification since such is the music taste of 1970 s, while in 2016 version various genre of music is included to adjust with the taste of 2016 society to strengthen the mood of the movie. In terms of sound effect, the context of $1970 \mathrm{~s}$ original is reproduced in 2016 movie particularly with the use of handle talkie to represent an identity of security officer. In the visual scene of introducing CHIPS unit members, 2016 version of the movie attempts to maintain the impression and shooting style 1970 s original version by framing CHIPS officers patrolling on a road getting ready to handle social problems.

\section{CONCLUSION}

The findings of the research show that both movies have similar characteristics. Similarity of audio characteristics (dialogue, music, and sound effect) takes place between Warkop DKI Reborn 2016 and Warkop DKI CHIPs 1982. In terms of audio, their dialogues are similar in characteristics, and also strengthening each other's typical periodical identity. In terms of visual, much like the case of audio, both seems to have similar scene of action, yet both still maintain typical characteristics, and in effect the same scene of both movies has the sense of nostalgic impression.

This finding audio and visual recontextualization in the movies proves that there is an effort to reproduce the contextual period of 1970s original movie in 2016 version based on new contemporary perspective. However, the 2016 version still maintain 1970s context. For example in audio recontextualization expression uttered by Dono, Kasino and Indro is reproduced in 2016 version for similar purpose, yet is still maintained to be relevant with each other's era. Furthermore in visual recontextualization of both movies, it is concluded that 2016 version managed to reproduce the context without ignoring the different habitual consideration of each era. So there is a kind of reciprocal attempts in defending both the original characteristics of the movie and the reproduced characteristics according to the available and forthcoming context in order to strengthen the mood of the movie.

\section{REFERENCES}

[1] Ardianto, Elvinaro \& Q-Anees, Bambang (2014). Filsafat Ilmu Komunikasi. Bandung: Simbiosa Rekatama Media.

[2] Bordwell, David (2001). Film Art: An Introduction. New York: Quebecor Printing Book Group/Dubuque.

[3] Mulyana, Deddy (2012). Ilmu Komunikasi: Suatu Pengantar. Bandung: PT. Remaja Rosdakarya Offset.

[4] Pratista, Himawan (2008). Memahami Film. Yogyakarta: Homerian Pustaka.

[5] Reed, Isaac Ariail (2011). Interpretation and Social Knowledge. Chicago: The University of Chicago Press.

[6] Sani, Asrul (1984). Cara Menghayati Sebuah Film. Jakarta: Yayasan Citra.

[7] Satori, Djam'an (2014). Metodologi Penelitian Kualitatif. Bandung: Alfabeta.

[8] Suwardi, Harun (2006). Kritik Sosial Dalam Film Komedi. Jakarta: FFTV-IKJ Press.

[9] Yusuf, Muri (2014). Metode Penelitian: Kuantitatif, Kualitatif, dan Penelitian Gabungan. Jakarta: Prenadamedia. 